among women internally displaced in Mississippi 2 years post-Hurricane Katrina. Disaster Med Public Health Preparedness. 2009;3:18-26.

3. World Health Organization. WHO Multi-country Study on Women's Health and Domestic Violence Against Women. http://www.who.int/ gender/violence/who_multicountry_study/en/index.html. Accessed March 25, 2009

4. Larrance R, Anastario M, Lawry L. Health status among internally displaced persons in Louisiana and Mississippi travel trailer parks. Ann Emerg Med. 2007;49:590-601.

5. Tjaden P, Thoennes N. Prevalence, Incidence, and Consequences of Violence Against Women: Findings From the National Violence Against Women Survey. http://www.ncjrs.gov/txtfiles/172837.txt. Accessed March 25, 2009.

6. Centers for Disease Control and Prevention. 2006 Behavioral Risk Factor Surveillance System Questionnaire. http://www.cdc.gov/brfss/ questionnaires/pdf-ques/2006brfss.pdf. Accessed March 25, 2009.

7. Mississippi Department of Health. Behavioral Risk Factor Surveillance System Home. http://www.msdh.state.ms.us/brfss/index.htm. Accessed March 25, 2009.

8. Ward J. Violence Against Women: A Statistical Overview, Challenges and Gaps in Data Collection and Methodology and Approaches for Overcoming Them. UN Division for the Advancement of Women in collaboration with Economic Commission for Europe (ECE) and World Health Organization (WHO) Expert Group Meeting. http://www.un.org/ womenwatch/daw/egm/vaw-stat-2005/docs/expert-papers/Ward.pdf. Accessed March 25, 2009.

9. World Health Organization. WHO Ethical and Safety Recommendations for Researching, Documenting and Monitoring Sexual Violence in Emergencies. http://www.who.int/gender/documents/OMS_EthicsESSafety10 Aug07.pdf. Accessed March 25, 2009.

10. Crime in the United States 2004 Uniform Crime Reports. http://www. fbi.gov/filelink.html?file=/ucr/cius_04/documents/CIUS2004.pdf. Accessed March 25, 2009.

11. United Nations International Research and Training Institute for the Advancement of Women. What Is Gender Based Violence? http:// www.un-instraw.org/en/index.php? option $=$ contentËtask $=$ view $\mathcal{E} i d=909$ Eु Itemid=0. Accessed March 25, 2009.

12. Reproductive Health Response in Conflict Consortium. Gender-Based Violence Tools Manual: For Assessment, Program Design, Monitoring and Evaluation in Conflict-Affected Settings http://www.rhrc.org/ resources/gbv/gbv_tools/manual_toc.html. Accessed March 25, 2009.

13. Anastario MP, Larrance R, Lawry L. Using mental health indicators to identify postdisaster gender-based violence among women displaced by Hurricane Katrina. J Womens Health (Larchmt). 2008;17:1437-1444.

\section{DISASTER 101: A NOVEL APPROACH TO HEALTH CARE STUDENTS' DISASTER MEDICINE AND EMERGENCY PREPAREDNESS TRAINING}

\section{To the Editor:}

Calls to develop skill-based competencies for emergency preparedness for health professionals-including physician trainees-predate the terrorist attacks of September 11, 2001. In June 2001, an American College of Emergency Physicians task force recommended that residents and medical students achieve proficiency in bioterrorism and weapons of mass destruction. ${ }^{1}$ Unfortunately, in the years following the 9/11 terrorist attacks, emergency preparedness education assessment largely focused on practicing physicians and not trainees..$^{2-5}$

In 2003, the Association of American Medical Colleges and the Institute of Medicine published reports encouraging early introduction of bioterrorism topics in medical school. The Association of American Medical Colleges report Training
Future Physicians about Weapons of Mass Destruction was the first to detail a vertical integration of bioterrorism curricula into all 4 years of medical education. ${ }^{6}$ In response to these reports, medical schools increased the attention paid to bioterrorism topics. In 2004, of 125 US medical schools, 104 reported that "biological/chemical terrorism" was included in $\geq 1$ required medical school courses. ${ }^{7}$

Yet US medical schools have been slow to develop standalone curricula that capture the academic breadth of disaster medicine. For example, a search of the Association of American Medical Colleges Course Details database using the terms "disaster," or "preparedness," or "casualty," or "bioterrorism," or "triage," revealed only 2 courses with any of the above terms in their title. ${ }^{8}$ With the exception of the notable work from some of our public health educators-for example, those at Columbia University-few medical schools have implemented core competencies for all health professionals in emergency preparedness such as those recently advocated by the American Medical Association's Expert Working Group. ${ }^{9}$

Thus, disaster medicine and emergency preparedness remain peripheral components of traditional medical education in the United States. Research on this topic is also lacking. We found only 2 published articles that specifically address the feasibility and efficacy of implementing disaster training to medical students. ${ }^{10,11}$

To address this research and training gap, we developed a 3-hour educational demonstration project to determine whether there was a novel method to teach medical students key concepts of disaster medicine. Using a pre-/posttest design, we measured the extent to which fourth-year medical students perceive, rapidly learn, and apply basic concepts of disaster medicine and emergency preparedness.

We sought to introduce concepts of disaster medicine immediately without the necessity of seeking university approval for a new course or changing an existing course. An application was submitted to the Office of Medical Education to offer our course, "Disaster 101," as an elective for fourth-year medical students.

An expert curriculum panel was convened consisting of 4 emergency medicine faculty physicians along with paramedic, emergency management, law enforcement, education, and training experts from the South Carolina Allied Health Education Consortium. The primary goal of the expert panel was to condense dozens of hours of existing lecture material into just 3. Via a modified Delphi technique, the panel pared down hundreds of competencies and competency domains into just 8 . In addition to a 90-minute didactic, 2 performance-based training exercises were developed. These included a hazardous material scene where students dressed and decontaminated a patient exposed to a toxin and a surprise mass casualty incident scenario with 100 life-sized mannequins.

Nearly all of the students who completed the 3-hour course accomplished their mass casualty incident performance ob- 
jectives, improved upon their pretest scores, and rated their overall knowledge as significantly improved after the course. Students rated the disaster training extremely highly. In fact, "Disaster 101" was one of the highest-rated courses in the 2008 fourth-year selective.

Overall, we used existing resources and local expertise and showed that fourth-year medical students can learn basic concepts of disaster medicine in a short period of time. We also did this without undermining the content or limiting the length of a single medical school course. The results of this educational demonstration project reveal that students will value and can rapidly learn some core elements of disaster medicine and emergency preparedness via a novel addition to a medical school's curriculum. We believe the principle of a highly effective and well-received medical student course that can be added without undermining current curriculum has been demonstrated here. Further research is needed to validate core competencies and performance-based education goals for all health trainees.

Lancer Alan Scott, MD

Medical University of South Carolina

DOI: 10.1097/DMP.0b013e3181b7e666

\section{REFERENCES}

1. Waeckerle JF, Seamans S, Whiteside M, et al. Executive summary: developing objectives, content, and competencies for the training of emergency medical technicians, emergency physicians, and emergency nurses to care for casualties resulting from nuclear, biological, or chemical incidents. Ann Emerg Med. 2001;37:587-601.

2. Gershon RR, Qureshi KA, Sepkowitz KA, et al. Clinicians' knowledge, attitudes, and concerns regarding bioterrorism after a brief educational program. J Occup Environ Med. 2004;46:77-83.

3. Chen FM, Hickner J, Fink KS, et al. On the front lines: family physicians' preparedness for bioterrorism. J Fam Pract. 2002;51:745-750.

4. Rico E, Trepka M, Guoyan Z, et al. Knowledge and attitudes about bioterrorism and smallpox: a survey of physicians and nurses. Florida Department of Health Web site. 2002. http://www.dadehealth.org/downloads/ dc_0702.pdf. Accessed July 30, 2009.

5. Lanzilotti SS, Galanis D, Leoni N, et al. Hawaii medical professionals assessment: a study of the availability of doctors and nurses to staff nonhospital, field medical facilities for mass casualty incidents resulting from the use of weapons of mass destruction and the level of knowledge and skills of these medical professionals as related to the treatment of victims of such incidents. Hawaii Med J. 2002;61:162-172.

6. Training Future Physicians About Weapons of Mass Destruction: Report of the Expert Panel on Bioterrorism Education for Medical Students. www.aamc.org/newsroom/bioterrorism/bioterrorismrec.pdf. Accessed February 13, 2009.

7. Number of US Medical Schools Teaching Selected Topics 2004-2005. Association of American Medical Colleges Web site. http://services. aamc.org/currdir/section2/04_05hottopics.pdf. Accessed February 13, 2009.

8. Curriculum Directory. Association of American Medical Colleges Web site. $h t$ tt://services.aamc.org/currdir/section $4 /$ start.cfm. Accessed February 13, 2009.

9. Subbarao I, Lyznicki JM, Hsu EB, et al. A consensus-based educational framework and competency set for the discipline of disaster medicine and public health preparedness. Disaster Med Public Health Preparedness. 2008;2:57-68.

10. Coico R, Kachur E, Lima V, et al. Guidelines for preclerkship bioterrorism curricula. Acad Med. 2004;79:366-375.

11. Parrish AR, Oliver S, Jenkins D, et al. A short medical school course on responding to bioterrorism and other disasters. Acad Med. 2005;80:820-823. 